\title{
The amygdala: inside and out
}

\section{Ahmad R. Hariri ${ }^{*}$ and Paul J. Whalen ${ }^{2}$}

Addresses: ${ }^{1}$ Duke University, Department of Psychology \& Neuroscience, Institute for Genome Sciences \& Policy, 417 Chapel Drive, Room 317 , Box 90086, Durham, NC 27708-0086, USA; ${ }^{2}$ Dartmouth College, Department of Psychological \& Brain Sciences, 6207 Moore Hall, Room 349 , Hanover, NH 03755, USA

*Corresponding author: Ahmad R. Hariri (ahmad.hariri@duke.edu)

Fl000 Biology Reports 201I, 3:2 (doi:10.3410/B3-2)

This is an open-access article distributed under the terms of the Creative Commons Attribution-Non Commercial License (http://creativecommons.org/licenses/by-nc/3.0/legalcode), which permits unrestricted use, distribution, and reproduction in any medium, provided the original work is properly cited. You may not use this work for commercial purposes.

The electronic version of this article is the complete one and can be found at: http://fl000.com/reports/b/3/2

\begin{abstract}
Research at the interface of psychology, neuroscience, molecular biology, and genetics, focusing on the amygdala, has begun to reveal a rule book for emotional reactions. Variations in intrinsic and extrinsic factors tweak the sensitivity of the amygdala, giving rise to differences in behavior between individuals. At their most extreme, these variations may generate psychological disorders, and even our current rudimentary understanding of this brain region suggests novel strategies for the treatment of such disorders.
\end{abstract}

In this report, we provide an overview of the innovative approaches and subsequent findings that have contributed to the discovery of specific factors that elucidate how a relatively small portion of our brain called "the amygdala" can dictate a significant number of the behaviors that make up our emotional lives. The amygdala is a deep-brain structure that is uniquely positioned to filter the constant barrage of input from our external and internal worlds. It is the sensitivity of this structure that dictates how the rest of the brain will convert those signals into adaptive behavioral and physiological responses. Fundamentally, the amygdala is critical to detecting and initiating the learning that allows us to use environmental events to predict potential threats. Whether it is a rat in a cage learning that the tone it hears heralds a mild electric shock, or a human realizing that someone is coming up behind them because the person in front of them just widened their eyes, it is the amygdala that calls the "rest of the brain" into action so its smarter "parent" can decide what to do (or not to do) next. Abnormal variations in amygdala reactivity can lead to exaggerated reactions to both intrinsic (biological) and extrinsic (environmental) signals, leading to the disorders we experience as depression and anxiety. The past ten years have borne witness to remarkable progress in our understanding of the intrinsic and extrinsic factors that modulate the responsiveness of the amygdala and its effects on behavior and physiology. These advances offer the beginnings of an understanding that addresses why different individuals respond to adversity and challenge in ways that range from submission to resilience. Critically, these studies have uncovered novel neurobiological targets for the treatment and even prevention of psychopathological states.

\section{Intrinsic factors}

Three complimentary strategies have proven particularly useful in identifying specific intrinsic factors that help shape the responsiveness of the human amygdala [1]. Each of these three approaches is based on the ability to accurately measure inter-individual differences in amygdala function through blood oxygen level-dependent functional magnetic resonance imaging (BOLD fMRI). In the first strategy, commonly referred to as pharmacologic fMRI, a drug that is a specific antagonist or agonist of a targeted neuromodulatory system is administered to subjects either shortly before or during BOLD fMRI. The effects of the drug on brain function are typically compared to the effects of a placebo. Ideally, a doubleblinded design is employed so that neither the participants nor the investigators are aware which treatment is 
being administered until all data have been collected. Any differences in brain function between the drug and placebo groups reflect a specific role in the brain circuitry for the neuromodulatory system under investigation. Such pharmacologic fMRI research has demonstrated that several neuromodulatory systems, including dopamine $[2,3]$, serotonin $[4,5]$, norepinephrine $[6,7]$, GABA [8], endocannabinoids [9], and steroid hormones [10-12], affect the responsiveness of the human amygdala. Although pharmacologic fMRI studies like those noted above are useful for identifying specific systems that modulate the human amygdala, they do not identify inter-individual differences in the intrinsic functioning of these systems and the resulting variability in the responsiveness of the amygdala.

The second strategy addresses these shortcomings by combining BOLD fMRI with neuroreceptor positron emission tomography (PET). A significant number of molecules involved in neuromodulatory signaling cascades such as biosynthesis, release, reuptake, and cell-signaling can be assayed in vivo using PET ligands. By combining these PET-derived measures of brain chemistry with BOLD fMRI data in the same participants, intrinsic regional levels of specific neuromodulatory targets can be systematically related to brain function. Already, such multimodal PET/fMRI studies have identified predictive links between inter-individual differences in amygdala responsiveness and endogenous variability in the serotonin [13-15] and dopamine $[16,17]$ systems. These effects are not only consistent with those observed in pharmacologic fMRI studies but also serve to establish how naturally occurring variability in these neuromodulatory systems shapes amygdala functioning.

The third complimentary research strategy, imaging genetics, seeks to establish connections between common genetic polymorphisms, variability in neuromodulatory systems and inter-individual differences in brain function. Thousands and possibly millions of common polymorphisms (i.e., those variations in a gene that are present in more than $1 \%$ of the population) exist across the entire human genome. By affecting the pathways between genes and their protein products, these polymorphisms can cause significant variability in the functioning of neuromodulatory systems between individuals. Combining information on these common functional genetic polymorphisms with BOLD fMRI data from the same group of participants, we can map the variability in neuromodulatory function associated with the polymorphisms onto differences in brain function between individuals. Many imaging genetic findings of amydala function are consistent with patterns reported in pharmacologic fMRI and multimodal
PET/fMRI studies. This includes confirmation of the role of serotonin $[18,19]$, dopamine [20-22], norepinephrine [23], endocannabinoids [24], and steroid hormones $[25,26]$. However, imaging genetics research has also broken new ground in identifying specific intrinsic factors that shape variability in amygdala responsiveness in the absence of a priori pharmacologic fMRI or multimodal PET/fMRI findings [27-29]. Unlike the first two research strategies, which are limited by the number of available drugs or ligands, respectively, imaging genetics offers the potential to explore the impact of any factor whose function may be affected by common variation in its genetic code. Thus, imaging genetics holds unique promise in identifying a broad array of intrinsic factors that contribute to interindividual differences in the responsiveness of the human amygdala.

Regardless of the specific strategy, the intrinsic factors identified through the above research are largely consistent with the identified roles of the amygdala, the target neuromodulatory systems, and the genetic polymorphisms that have been implicated in the expression of normal emotional behavior as well as psychopathology (particularly mood and anxiety disorders). Moreover, these intrinsic factors, which modulate amygdala responsiveness, may be useful predictive markers of relative risk for psychopathology. Even more intriguingly, they suggest specific mechanisms for the development of individually tailored treatment and, ultimately, prevention strategies for psychopathology.

\section{Extrinsic factors}

Numerous studies have shown that increased amygdala responsiveness is critical to acquiring a learned state of fear during aversive conditioning [30]. During these learned states, the amygdala mediates common adaptive responses that allow the animal to learn best-examples of these responses are autonomic responses such as heart rate and respiration as well as somatomotor (movementrelated) responses such as freezing [31-34]. Critically, the amygdala's role in mediating these behaviors is particularly important during learning when the outcome predicted by a particular stimulus is uncertain, be it (a) early in training, (b) when a particular contingency has changed, or (c) when a cue can lead to more than one outcome [33]. The key to elucidating the role of the amygdala during learning is to devise tasks that set aside a strong fear state that can overshadow the direct study of the amygdala. For example, while early studies aimed to present the human amygdala with stimuli that would produce strong emotional state changes, recent studies have opted to present more "emotionally subtle" stimuli to assess the amygdala's role in learning. 
Photographs of facial expressions are often used as stimuli in this context because we can glean information about someone's internal emotional state, their intentions, and their reaction to events in our immediate environment from their expressions. Facial expressions of emotion have predicted important events for us in the past, and we can use these previous experiences to respond appropriately to expressions as we perceive them. In this way, facial expressions are naturally conditioned stimuli.

If the amygdala is constantly monitoring something as subtle as changes in facial expression then it is playing a fundamental role in modulating our moment-tomoment vigilance and learning [33]. The implications this perspective has for amygdala dysfunction are therefore enormous. Aberration in this system would lead to very basic interpersonal dysfunction that could lie at the heart of a host of psychological disorders. Indeed, facial expressions have been used as stimuli to identify abnormal amygdala responses in many disorders $[35,36]$ and, more importantly, have been used to predict treatment outcomes in specific disorders including generalized anxiety disorder $[37,38]$.

\section{Recent advances}

Some useful research concerning amygdala reactions to extrinsic events has addressed its role in processing explicit versus implicit emotional events. That is, those events and responses that we are consciously aware of, and those that we are not. Being aware of your emotional response to a particular environmental stimulus is clearly beneficial. For example, knowing that your ex-wife causes your blood to boil is a good thing to remind yourself of before heading to an extended family function. However, we are not always aware of the emotional "triggers" that set us off, for example, sometimes we are in the middle of a social situation and look down and realize that we are sweating. Numerous studies have now examined whether the amygdala is sensitive to these environmental events that escape our awareness. Much like the field of human memory, the study of human emotion is beginning to elucidate the importance of implicit versus explicit processing of emotional information.

The early human neuroimaging work addressing implicit emotion used a technique called backward masking to present fearful facial expressions in a way that increased amygdala activity without the participant being consciously aware of their presence $[39,40]$, a technique derived from the seminal psychophysiological studies of Arne Öhman [41,42]. Perceptual illusions other than backward masking, such as binocular rivalry and continuous flash suppression, have also been used to demonstrate similar implicit effects [43,44]. However, contrived experimental manipulations are not the only way such effects can be shown. It is probably more compelling to show such effects when subjects could have been aware of the trigger. Demos and colleagues [45] presented subjects with female faces and then told them that a single facial feature had been manipulated. Though none of the subjects were able to state what the change was, their amygdala did by discriminating between faces with large compared to small pupils. Since stimulation of the amygdala produces pupil dilation, this is an example of the amygdala showing sensitivity to an emotional response in others that it controls in one's self.

In another example, Mujica-Parodi and colleagues [46] presented their subjects with sweat samples from individuals who had either just completed their first sky dive or exercised on a treadmill. The subjects could not possibly have known which of the samples were from people experiencing their first sky dive, but their amygdala knew, showing a larger response to the samples derived from first-time sky divers. Therefore, if another person in my immediate environment is in an excitable state, even if I don't know the reason myself, perhaps I will have some sense for that and react accordingly.

Todorov and colleagues $[47,48]$ provide one of our favorite examples of the utility of separating amygdala responses into "things I can explicitly tell you about" from "those that I cannot." Subjects were presented with many pictures of faces, all intended to have no discernable expression (i.e., neutral). The subjects were asked to tell the experimenters how trustworthy they thought each face was based on a gut reaction. As expected, each subject thought some of the faces were more trustworthy-looking, some were in the middle, and some were less trustworthy-looking. Not surprisingly, their amygdala responses to these faces also matched their verbal assessments. From a large number of varied ratings, the researchers computed a mean trustworthiness score for each face. Fascinatingly, although the test group's amygdala responses correlated with their own subjective verbal ratings of the faces, their amygdala responses showed an even stronger relationship with the consensus ratings for each face! The implications of this finding are many, but most importantly it means that "there are rules"-implicit rules about certain facial features that guide our amygdala reactions and, in turn, our behavior. Although we can modulate these reactions once we become aware of them, we have less control over their initiation. 


\section{Future directions}

These examples of implicit emotional processing are sometimes passed off as "cute" novelties. But we suggest that they will be critical to fully understanding our emotional lives and their aberrations in psychopathology. Depression and anxiety are not explicit emotional behaviors-they are, at their core, exaggerated implicit emotional reactions that have not been properly regulated. Identification of the genetic signatures that predict these exaggerated reactions, as well as the compromised prefrontal function that yields to these exaggerations, will clarify the predisposition of particular individuals to psychopathology. Combining information gleaned from examining implicit and explicit emotional function with measurement of the genetic markers that help shape each individual's "trigger" point, is one clear future direction that will yield benefits for the field.

\section{Abbreviations}

BOLD fMRI, blood oxygen level-dependent functional magnetic resonance imaging; PET, positron emission tomography.

\section{Competing interests}

The authors declare that they have no competing interests.

\section{References}

I. Hariri AR: The neurobiology of individual differences in complex behavioral traits. Annu Rev Neurosci 2009, 32:225-47.

2. Hariri AR, Mattay VS, Tessitore A, Kolachana B, Fera F, Goldman D, Egan MF, Weinberger DR: Serotonin transporter genetic variation and the response of the human amygdala. Science 2002, 297:400-3.

\section{FI000 Factor 6 \\ Evaluated by Joseph LeDoux 18 Oct 2002}

3. Tessitore A, Hariri AR, Fera F, Smith WG, Chase TN, Hyde TM, Weinberger DR, Mattay VS: Dopamine modulates the response of the human amygdala: a study in Parkinson's disease. J Neurosci 2002, 22:9099-103.

4. Bigos KL, Pollock BG, Aizenstein HJ, Fisher PM, Bies RR, Hariri AR: Acute 5-HT reuptake blockade potentiates human amygdala reactivity. Neuropsychopharmacology 2008, 33:322I-5.

5. Murphy SE, Norbury R, O'Sullivan U, Cower PJ, Harmer CJ: Effect of a single dose of citalopram on amygdala response to emotional faces. Br J Psychiatry 2009, 194:535-40.

6. Onur OA, Walter H, Schlaepfer TE, Rehme AK, Schmidt C, Keysers C, Maier W, Hurlemann R: Noradrenergic enhancement of amygdala responses to fear. Soc Cogn Affect Neurosci 2009, 4:119-26.

7. Hurlemann R, Walter H, Rehme AK, Kukolja J, Santoro SC, Schmidt C, Schnell K, Musshoff F, Keysers C, Maier W, Kendrick KM, Onur OA: Human amygdala reactivity is diminished by the beta-noradrenergic antagonist propranolol. Psychol Med 40:1839-48.

8. Paulus MP, Feinstein JS, Castillo G, Simmons AN, Stein MB: Dosedependent decrease of activation in bilateral amygdala and insula by lorazepam during emotion processing. Arch Gen Psychiatry 2005, 62:282-8.
9. Phan KL, Angstadt M, Golden J, Onyewuenyi I, Popovska A, de Wit H: Cannabinoid modulation of amygdala reactivity to social signals of threat in humans. J Neurosci 2008, 28:2313-9.

FI000 Factor 6

Evaluated by Ahmad Hariri 22 Aug 2008

10. Kirsch P, Esslinger C, Chen Q, Mier D, Lis S, Siddhanti S, Gruppe H, Mattay VS, Gallhofer B, Meyer-Lindenberg A: Oxytocin modulates neural circuitry for social cognition and fear in humans. J Neurosci 2005, 25: I|489-93.

FI000 Factor 6

Evaluated by Oliver Wolf 20 Feb 2006

II. Domes G, Heinrichs M, Gläscher J, Büchel C, Braus DF, Herpertz SC: Oxytocin attenuates amygdala responses to emotional faces regardless of valence. Biol Psychiatry 2007, 62: I I87-90.

12. van Wingen G, Mattern C, Verkes RJ, Buitelaar J, Fernández G: Testosterone reduces amygdala-orbitofrontal cortex coupling. Psychoneuroendocrinology 2010, 35:105-13.

13. Fisher PM, Meltzer CC, Ziolko SK, Price JC, Moses-Kolko EL, Berga SL, Hariri AR: Capacity for 5-HTIA-mediated autoregulation predicts amygdala reactivity. Nat Neurosci 2006, 9: I362-3.

14. Rhodes RA, Murthy NV, Dresner MA, Selvaraj S, Stavrakakis N, Babar S, Cowen PJ, Grasby PM: Human 5-HT transporter availability predicts amygdala reactivity in vivo. J Neurosci 2007, 27:9233-7.

15. Fisher PM, Meltzer CC, Price JC, Coleman RL, Ziolko SK, Becker C, Moses-Kolko EL, Berga SL, Hariri AR: Medial prefrontal cortex 5-HT(2A) density is correlated with amygdala reactivity, response habituation, and functional coupling. Cereb Cortex 2009, 19:2499-507.

16. Kienast $T$, Hariri AR, Schlagenhauf $F$, Wrase J, Sterzer P, Buchholz HG, Smolka MN, Gründer G, Cumming P, Kumakura Y, Bartenstein P, Dolan RJ, Heinz A: Dopamine in amygdala gates limbic processing of aversive stimuli in humans. Nat Neurosci 2008, I I:| $38 \mid-2$.

17. Takahashi H, Takano H, Kodaka F, Arakawa R, Yamada M, Otsuka T, Hirano Y, Kikyo H, Okubo Y, Kato M, Obata T, Ito H, Suhara T: Contribution of dopamine DI and D2 receptors to amygdala activity in human. J Neurosci 2010, 30:3043-7.

18. Hariri AR, Mattay VS, Tessitore A, Fera F, Smith WG, Weinberger DR: Dextroamphetamine modulates the response of the human amygdala. Neuropsychopharmacology 2002, 27:1036-40.

19. Fakra E, Hyde LW, Gorka A, Fisher PM, Muñoz KE, Kimak M, Halder I, Ferrell RE, Manuck SB, Hariri AR: Effects of HTRIA C(-I OI9)G on amygdala reactivity and trait anxiety. Arch Gen Psychiatry 2009, 66:33-40.

20. Smolka MN, Schumann G, Wrase J, Grüsser SM, Flor H, Mann K, Braus DF, Goldman D, Büchel C, Heinz A: Catechol-O-methyltransferase vall58met genotype affects processing of emotional stimuli in the amygdala and prefrontal cortex. I Neurosci 2005, 25:836-42.

21. Drabant EM, Hariri AR, Meyer-Lindenberg A, Munoz KE, Mattay VS, Kolachana BS, Egan MF, Weinberger DR: Catechol O-methyltransferase vall58met genotype and neural mechanisms related to affective arousal and regulation. Arch Gen Psychiatry 2006, 63:1396-406.

22. Blasi G, Lo Bianco L, Taurisano P, Gelao B, Romano R, Fazio L, Papazacharias A, Di Giorgio A, Caforio G, Rampino A, Masellis R, Papp A, Ursini G, Sinibaldi L, Popolizio T, Sadee W, Bertolino A: Functional variation of the dopamine D2 receptor gene is associated with emotional control as well as brain activity and connectivity during emotion processing in humans. J Neurosci 2009, 29:14812-9.

23. Rasch B, Spalek K, Buholzer S, Luechinger R, Boesiger $P$, Papassotiropoulos A, de Quervain DJ: A genetic variation of the noradrenergic system is related to differential amygdala 
activation during encoding of emotional memories. Proc Natl Acad Sci U S A 2009, 106:19191-6.

FI000 Factor 6

Evaluated by Ahmad Hariri 18 Dec 2009

24. Hariri AR, Gorka A, Hyde LW, Kimak M, Halder I, Ducci F, Ferrell RE, Goldman D, Manuck SB: Divergent effects of genetic variation in endocannabinoid signaling on human threat- and rewardrelated brain function. Biol Psychiatry 2009, 66:9-16.

FI000 Factor 8

Evaluated by Harriet de Wit 20 May 2009

25. Meyer-Lindenberg A, Kolachana B, Gold B, Olsh A, Nicodemus KK, Mattay V, Dean M, Weinberger DR: Genetic variants in AVPRIA linked to autism predict amygdala activation and personality traits in healthy humans. Mol Psychiatry 2009, 14:968-75.

26. Manuck SB, Marsland AL, Flory JD, Gorka A, Ferrell RE, Hariri AR: Salivary testosterone and a trinucleotide (CAG) length polymorphism in the androgen receptor gene predict amygdala reactivity in men. Psychoneuroendocrinology 2010, 35:94-104.

27. Brown SM, Peet E, Manuck SB, Williamson DE, Dahl RE, Ferrell RE, Hariri AR: A regulatory variant of the human tryptophan hydroxylase-2 gene biases amygdala reactivity. Mol Psychiatry 2005, 1 0:884-8

28. Neumann SA, Brown SM, Ferrell RE, Flory JD, Manuck SB, Hariri AR: Human choline transporter gene variation is associated with corticolimbic reactivity and autonomic-cholinergic function. Biol Psychiatry 2006, 60: I 155-62.

29. Zhou Z, Zhu G, Hariri AR, Enoch MA, Scott D, Sinha R, Virkkunen M, Mash DC, Lipsky RH, Hu XZ, Hodgkinson CA, Xu K, Buzas B, Yuan Q, Shen PH, Ferrell RE, Manuck SB, Brown SM, Hauger RL, Stohler CS, Zubieta JK, Goldman D: Genetic variation in human NPY expression affects stress response and emotion. Nature 2008, 452:997-1001.

FI000 Factor 9

Evaluated by Angela Vincent 30 Apr 2008, Robert Sapolsky 29 Oct 2008

30. LeDoux J: The emotional brain. The mysterious underpinnings of emotional life. New York: Simon \& Schuster; 1996.

31. Kapp BS, Whalen PJ, Supple WF, Pascoe JP: Amygdaloid contributions to conditioned arousal and sensory information processing. In The Amygdala: Neurobiological Aspects of Emotion, Memory, and Mental Dysfunction. Edited by Aggelton JP. New York: Wiley-Liss; 1992, 229-54.

32. Gallagher M, Holland PC: The amygdala complex: Multiple roles in associative learning and attention. Proc Natl Acad Sci U S A |994, 9|: | |77|-6.

33. Whalen PJ: Fear, vigilance, and ambiguity: Initial neuroimaging studies of the human amygdala. Curr Dir Psychol Sci 1998, 7:177-88

34. Weisz DJ, Harden DG, Xiang Z: Effects of amygdala lesions on reflex facilitation and conditioned response acquisition during nictitating membrane response conditioning in rabbit. Behav Neurosci 1992, 106:262-73.

35. Phillips ML, Drevets WC, Rauch SL, Lane R: Neurobiology of emotion perception II: Implications for major psychiatric disorders. Biol Psychiatry 2003, 54:5 I 5-28.

36. Etkin A, Wager TD: Functional neuroimaging of anxiety: a meta-analysis of emotional processing in PTSD, social anxiety disorder, and specific phobia. Am J Psychiatry 2007, 164:|476-88.

37. Whalen PJ, Johnstone T, Somerville LH, Nitschke JB, Polis S, Alexander AL, Davidson RJ, Kalin $\mathrm{NH}$ : A functional magnetic resonance imaging predictor of treatment response to venlafaxine in generalized anxiety disorder. Biol Psychiatry 2008, 63:858-63.

38. Nitschke JB, Sarinopoulos I, Oathes DJ, Johnstone T, Whalen PJ, Davidson RJ, Kalin NH: Anticipatory activation in the amygdala and anterior cingulate in generalized anxiety disorder and prediction of treatment response. Am J Psychiatry 2009, 166:302-10.

39. Morris JS, Ohman A, Dolan RJ: Conscious and unconscious emotional learning in the human amygdala. Nature 1998, 393:467-70.

40. Whalen PJ, Rauch SL, Etcoff NL, Mclnerney SC, Lee MB, Jenike MA: Masked presentations of emotional facial expressions modulate amygdala activity without explicit knowledge. J Neurosci 1998, 18:41|-8.

4I. Esteves F, Ohman A: Masking the face: recognition of emotional facial expressions as a function of the parameters of backward masking. Scand J Psychol 1993, 34: I- I8.

42. Esteves F, Parra C, Dimberg U, Ohman A: Nonconscious associative learning: Pavlovian conditioning of skin conductance responses to masked fear-relevant facial stimuli. Psychophysiology 1994, 3 I:375-85.

43. Williams MA, Morris AP, McGlone F, Abbott DF, Mattingley JB: Amygdala responses to fearful and happy facial expressions under conditions of binocular suppression. J Neurosci 2004, 24:2898-904

44. Amting JM, Greening SG, Mitchell DG: Multiple mechanisms of consciousness: the neural correlates of emotional awareness. J Neurosci 2010, 30:10039-47.

45. Demos KE, Kelley WM, Ryan SL, Davis FC, Whalen PJ: Human amygdala sensitivity to the pupil size of others. Cereb Cortex 2008, I 8:2729-34.

46. Mujica-Parodi LR, Strey HH, Frederick B, Savoy R, Cox D, Botanov Y, Tolkunov D, Rubin D, Weber J: Chemosensory cues to conspecific emotional stress activate amygdala in humans. PLoS One 2009, 4:e64I5.

47. Engell AD, Haxby JV, Todorov A: Implicit trustworthiness decisions: automatic coding of face properties in the human amygdala. J Cogn Neurosci 2007, I9:1508-19.

48. Said CP, Baron SG, Todorov A: Nonlinear amygdala response to face trustworthiness: contributions of high and low spatial frequency information. J Cogn Neurosci 2009, 2 I:5 19-28. 